\title{
The Analysis of the SCP Paradigm of the Logistics Industry
}

\author{
Xingjin $\mathrm{Yu}$ \\ Department of Economic Management \\ North Chinese Electric University \\ Hebei,China \\ yxjbb123@163.com
}

\begin{abstract}
In this paper, we use the SCP analysis paradigm of the logistics industry in China, market structure, market behavior and market performance analysis, to describe the operations of the logistics industry in our country.Combined with the current market situation, put forward the constructive suggestions on the development of logistics industry.
\end{abstract}

Keywords-The logistics industry; Market structure; Market behavior; Market performance

\section{INTRODUCTION}

This paper argues that the logistics industry is engaged in the transportation, storage, loading and unloading, handling, distribution processing, distribution and logistics services such as logistics information collection, to specialized third-party logistics enterprises as the main body and provide the same service including producing and selling enterprises logistics department. The logistics industry is an important part of our national economy, is also a measure of a nation's modernization level and an important symbol of comprehensive national strength, is known as the "accelerator" of economic development. Logistics industry in our country has experienced from the professional to present the trend of specialization, diversification, the research of our country's logistics industry market structure, market behavior and market performance, analyzes the management status quo of strengthening government guidance, improve the logistics industry on the economy contribution is of great significance.

\section{MARKET STRUCTURE}

The concept of market structure is the most basic SCP analytical framework and research topics, refers to the inner link between the various elements in a market and its characteristics, reflect the relative degree of market competition and monopoly. Decision factors mainly include the market structure of industry of the degree of market concentration, product differentiation, barriers to entry, exit and other products.

\section{A. Market Concentration Rate}

Market concentration is the market structure of the whole industry concentration measurement, it is used to measure the number of enterprise and relative size differences, is an important quantitative indicators of market power. Commonly used measure of industry concentration, fanta - Hector seaman, the gini coefficient and the entropy index and so on.

Table.1-2008-2010 China logistics market concentration

\begin{tabular}{c|c|c|c}
\hline \multicolumn{4}{|c}{ concentration } \\
\hline 2008 & $\boldsymbol{C R}_{4}$ & $\boldsymbol{C R}_{8}$ & Market Types \\
\hline 2009 & $8.36 \%$ & $10.47 \%$ & Particles in the market \\
\hline 2010 & $9.49 \%$ & $9.69 \%$ & Particles in the market \\
\hline 2014 & $4.8 \%$ & $7.2 \%$ & Particles in the market \\
\hline
\end{tabular}

According to Bain's market structure classification market belongs to the particles of the logistics industry in our country, concentration is very low, is fragmented, logistics companies and resources industries has internal appeal and influential large enterprises, the logistics market in the perfect competition stage. Logistics industry in China focus on defect main performance is: the low level of specialization; Low excessive investment, hindered the development of service industry high-end. This kind of extensive development pattern, it is difficult to make logistics enterprises are difficult to achieve economies of scale, can effectively improve the consumer welfare. So if you want to more improve concentration, increase the competitiveness of logistics enterprises, for logistics enterprises to strengthen the guidance, prompting them to achieve economies of scale, and reduce operating costs, achieve the reasonable configuration of resources.

Table 2 -Bain's market structure type of method

\begin{tabular}{l|c|c}
\hline Market Structure & $C R_{4}(\%)$ & $C R_{8}(\%)$ \\
Concentration Ratio & & \\
& & \\
\hline Oligopoly Type I & $C R_{4} \geq 85$ & - \\
\hline Oligopoly Type II & $75 \leq C R_{4}<85$ & $C R_{8} \geq 85$ \\
\hline Oligopoly Type III & $50 \leq C R_{4}<75$ & $75 \leq C R_{8}<85$ \\
\hline Oligopoly Type IV & $35 \leq C R_{4}<50$ & $50 \leq C R_{8}<75$ \\
\hline Oligopoly Type V & $30 \leq C R_{4}<35$ & $35 \leq C R_{8}<50$ \\
\hline Competitive Type & $C R_{4}<30$ & $C R_{8}<30$ \\
\hline
\end{tabular}




\section{B. Differentiation of Product (Service)}

Product Differentiation refers to the enterprise to change the same Product in some way, in order to make consumers believe that the differences between the products and produce different preferences. Logistics is the integration complex service industries such as transportation, warehousing and information sector, so for the logistics industry, there are large difference between different areas of the profit space, so improve the differentiation can not only make the enterprise in the field of logistics business expanding customer base, but also can improve the overall profitability of enterprises, enhance the enterprise the overall competitiveness.

The difference of the logistics industry in logistics specialization degree and the level of service, the information technology, logistics standard has difference. In the process of logistics services, customers often through previous dealings between logistics enterprises and establish a stable long-term business partnership, this relationship can produce consumer preferences, so that the service is different from other enterprises.

\section{Barriers to Entry}

Barriers to entry refers to enter a market of the sum of all kinds of obstacles, mainly displays in the incumbent firms has absolute cost advantages, the advanced management experience, preempt market advantages make potential entrants if you want to enter the market need to pay a huge cost, so the potential entrants are difficult to enter. The entry barriers of the logistics industry in our country mainly displays in: product (service) differential barriers, transforming to modern enterprise logistics enterprises in China, can really almost non-existent in the leading logistics companies, the low level of logistics operation, high operating costs and low efficiency, the overall satisfaction with the service is poor. So, for potential entrants, degree of product difference is very small, almost non-existent. Barriers to absolute cost advantages, due to the logistics industry is broad, mass transportation, warehouse, the informatization of cash.

To sum up, our country's logistics industry market structure as a whole enterprise quantity, market concentration is not high. From providing services of difference degree, in the logistics industry in our country, the low degree of the specialization of logistics, logistics service co., LTD., single function, logistics service level is still relatively low. Logistics market of the low barriers to entry and exit barriers is higher. For the logistics industry, need to carefully analyze the market structure of the logistics industry in China, as soon as possible, adjust the management goal and strategy, implement customer satisfaction theory, customer satisfaction management, to establish new competitive advantages, realize win-win situation of enterprise and customer.

\section{MARKET CONDUCT}

Before you begin to format your paper, first write and save the content as a separate text file. Keep your text and graphic files separate until after the text has been formatted and styled. Do not use hard tabs, and limit use of hard returns to only one return at the end of a paragraph. Do not add any kind of pagination anywhere in the paper. Do not number text heads-the template will do that for you.
Finally, complete content and organizational editing before formatting. Please take note of the following items when proofreading spelling and grammar:

\section{A. The Price Behavior}

The main factors influencing the logistics service product pricing is cost factors, market factors, national policy, consumer behavior and psychological factors. The logistics industry in our country mostly adopts the costplus pricing method, because of the characteristic of the logistics industry is the low concentration, so the market price is unable to form the monopoly price, mainly composed of price competition. Logistics cost price competition is a main differential pricing, this is mainly related to the distance of transport, goods and the mode of transportation.

\section{B. Non-price Behavior}

Non-price behavior is an important form of monopoly competition, is the manufacturer of the products under the premise of constant price conditions with the aid of the differences between tangible and intangible, advertising and other forms of marketing a form of selling products, participate in market competition. Logistics industry main non-price behavior by providing specific services, improve service quality, advertising campaign to educate consumers specific preference, in order to improve their competitiveness and gain more market share.

Moreover mergers and innovation forms of non-price competition of logistics industry, logistics industry chain is very complex, mainly related to automobile manufacturing, logistics, real estate, information technology, logistics technology, logistics equipment, external transaction cost is very high, so the m\&a main form of the logistics industry has to expand and realize the comprehensive service of horizontal mergers and acquisitions and integrated industrial chain upstream and downstream of the longitudinal mergers and acquisitions. Of technology is very much involved in the logistics industry and logistics should be done quickly and efficiently logistics distribution, logistics industry is becoming more and more high to the requirement of technology, and with the concept of "green logistics" is put forward, how to strengthen the investment research and development strength, promote the technology innovation of logistics industry, to reduce logistics costs, improve due to the traditional way of logistics distribution and pollution of the environment of the problems of packaging equipment is heavy.

With various aspects of technology innovation, the traditional logistics is no longer, but the combination of technology driven by emerging logistics, the logistics will be the first to occur within the enterprise and growth, and then will be extended to the whole industry, eventually to promote the integration of logistics into the big, big change, a new stage of breakthrough.

\section{MARKET PERFORMANCE}

Market performance reflects the certain specific market structure and market behavior under the market operation of the actual result. In the sustained economic growth and policy implementation, the added value of the logistics industry maintained a fast growth in our country, operation 
quality and efficiency improved significantly. And logistics industry's contribution to the quality and efficiency of the national economy is more and more big, the 2013 national logistics industry added value 3.9 trillion yuan, calculated at comparable prices, up $8.5 \%$ from a year earlier, the growth rate fell by $0.7 \%$ over the previous year. The added value of the logistics industry as a share of GDP is $6.8 \%$, the proportion of the added value of service industry is $14.8 \%$.

Although the development of logistics industry in our country has got a large, in 2014 China's logistics industry present "growth is slowing, quality improvement," the basic characteristics of national logistics industry climate index LPI average is $54.8 \%$, reflecting the overall is still in the stable development of China's logistics industry, compared with 2013 LPI average rose $53.1 \%$, but growth is slowing.

\section{THE CONCLUSION AND SUGGESTION}

Since the logistics industry development in our country has the government's vigorously support, and to our country's economic development has a great role in promoting. Due to the low concentration, but the logistics industry entrants more, industry operation cost is high, the efficiency is low, although great progress has been made, but the growth rate fell.

This paper puts forward the following five Suggestions on the development of China's logistics industry: a this article put forward the following five Suggestions on the development of China's logistics industry a) Plan, and ensure that policy implementation to the concrete;

b) More to support the logistics industry, guide the logistics industry layout is reasonable

c) Come up with a strategy of internationalization of logistics industry development in our country, implementing "go out and introduced to" pattern, the combination of the logistics industry in our country can learn other countries of advanced logistics technology and management concept;

d) Preferential policy support, give policy on the protection and support

\section{REFERENCES}

[1] [1] Wen-sheng LIU LI YanFeng. Kang Zhaoyan. LIU Wen - sheng. LI Yan - Feng. KANG Zhao Yan, the logistics industry in our country's theory of SCP analysis $[\mathrm{J}]$ - logistics science and technology, 2006 (6)

[2] Mr Yang industrial organization analysis of third-party logistics master dissertation] [2006]

[3] The Yan. Bing-lian LIU. ZHI Yan. LIU Bin - lian the analysis of the characteristics of logistics industrial organization -- empirical study based on data from 2002 to 2005 [journal] - forecast 2007 (4)

[4] Deng hole hole SCP analysis of logistics industry in China, based on the data of listed companies in 2006-2006, logistics master 2012 [dissertation]

[5] Hong-yi XU. Yang Pei. XU Hong - yi. YANG Pei SCP theory for the application of the logistics industry in our country [journal] journal of huazhong agricultural university (social science edition), 2008 (5) 